\title{
The Exercise of Mandate - How Mandatory Service Implementation Promoted the Use of E-Government Services in Denmark
}

\author{
Mika Yasuoka \\ Roskilde University \\ mikaj@ruc.dk
}

\author{
Morten Meyerhoff Nielsen \\ United Nations University, EGov \\ meyerhoff@unu.edu
}

\author{
Karen Ejersbo Iversen \\ Danish Agency for Digitisation \\ kei@digst.dk
}

\begin{abstract}
Danish e-government has for two decades been considered a global leader. Among the various reasons for this Danish success, this article explores the mandatory online self-service and digital post initiative (2012-2015) as one of the effective, strategic contributions in increasing the wider penetration and use of digital public services in Danish society. Although the mandatory shift to digital service could have caused negative reactions from public servants and citizens, this was not the case in Denmark. By reviewing a set of mandatory digital public services in the Danish context, four key aspects are identified as essential drivers. That is: pride as citizens, high levels of trust and privacy, usability and accessibility of egovernment services, and informal support by family and community. The article discusses the four supportive prerequisites as keys for enforcing the implementations, which could otherwise be seen as national coercive dirigisme.
\end{abstract}

\section{Introduction}

Danish e-government (eGov) has long been regarded a front runner in governmental and public service digitization and digital transformation [1], [2], linking governmental institutions and services, and providing specialized portals and services to citizens and businesses [3]. According to the latest United Nations' E-Government Readiness Survey and Index [4], Danish eGov ranks number one. In the same survey, other countries who have similar or more advanced infrastructure such as Japan (14th) and similar types of internet use, eBanking and eCommerce, such as Sweden $\left(6^{\text {th }}\right)$ and the Netherlands $\left(10^{\text {th }}\right)$ have lower take-up of eGov services [5].

The reasons for this are argued widely. The relative size of countries has often been highlighted as one of the key factors of Danish eGov success, especially in comparison with large nations such as Brazil, China, and Japan. Certainly, small countries have advantages of simpler government structures and smaller databases. However, they are also challenged by other factors such as economic and human resource constraints [6], which rationalize that not all small countries have succeeded in eGov. As stated in the micro state digitalization of the Faroe Islands, a nation of 51,000 citizens, "digitalization is generally more difficult, less cost effective, and less likely to alter the size of the bureaucracy in smaller territories [6]". While digitization changes a way the public sector operates, it does not reduce the amount nor level of interaction with citizens. EGov is complicated regardless of the size of the country [6]. All the more, welfare states, like Denmark, offering a wider range of social services, could make public service digitization more complicated and extensive [3].

Apart from its relative size, what could the key factors behind Danish eGov successes be? Previous research identified several key enablers such as the cross-sectional cooperation models within and across central, regional and local governments [7]-[9], and focused governance, exemplified by the establishment of a specialized agency responsible for digitalization [1], [3], [7]. In addition to all these well discussed areas, this paper analyses a new aspect, 'mandate'. The Danish approach to a strategic and effective mandate, and a coordinated degree of mandatory obligations by the public sector and citizens, were widely exercised in the development and use of online services.

By following the trajectory of Danish eGov, it is evident that its path has not always been straightforward, as Danish authorities spent the 1990s and early 2000s implementing core digital public services with limited citizen adoption [10]. In order to promote smooth digitization, at some point in time, mandated and mandatory measures as strategic ingenuity were introduced to public institutions, businesses, and citizens, either in the form of national strategies and initiatives, standards or legislation [11].

Furthermore, while most eGov studies have taken place in settings from an organizational point of view [3], [5], a technology adaptation point of view such as the technology adaptation model (TAM) [12], or a citizens and businesses point of view as a free choice of digital services or coercive governmental dirigisme 
[5], [13], our study sheds light on a less investigated area, which is mandatory implementation of eGov services.

The structure of this paper is as follows. First, research methods and the dataset for the analysis are introduced. Section 3 summarizes the historical trajectory of Danish eGov, and then, in Section 4, among various mandatory services utilized during eGov implementation, three major mandatory services are introduced. Based on the examples, Section 5 discusses four perspectives on why a mandated and mandatory approach worked in Denmark. Finally, the paper provides specific remarks in relation to using mandatory implementation of eGov services.

\section{Research Methods and Data Collection}

This paper analyzes factors about Danish eGov strategies and services using mixed methods with multiple data sources. The mixed method is chosen since objective and subjective data are complementary overall socio-technical development and social contexts. Previous research indicates that implicit influencing factors behind the outcome are key to understanding the determinants of digital acceptance [14]. This cannot be done by objective literature analysis alone. Qualitative research can provide an extensive explanation for the reasons and factors behind Denmark as an emerging global leader in relation to the provision and use of eGov services.

More specifically, we review the literature, official strategies and reports published by the Danish government and international organizations such as the EU and the OECD. In addition, we conduct a set of targeted interviews with Danish experts and citizens working with or using eGov services. The official reports were used to understand the historical trajectory of Danish eGov and its service provision, with the complementing academic literatures. Essentially, the official reports are the six Danish national strategies [15]-[19], two OECD reports [20] [21], and a number of EU reports and publications [20], [22]-[24].

A total of 66 interviews were carried out between May 2020 to June 2021. The interview subjects (Table 1) were an age representative sample of Danish residents (50 interviewees), and relevant experts (16 interviewees) including academics, practitioners, and government officials. The interviews were conducted in Danish or English and recorded using a voice recorder or Teams/Zoom's recording function after interviewees' consent. After the interviews, the interview data was transcribed. The total interview time is 74.5 hours, equivalent to approximately one hour for each interview. The collected data was analyzed and categorized, using the KJ method [25], and a meta-synthesis analysis [26]. Finally, the results were synthesized with the reports and literatures.

The interviews are not meant to proportionally represent the views of each sector, but rather represent relevant knowledge and various perspectives. The authors therefore carefully selected a wide range of interviewees to eliminate biases. For example, the interviews with citizens included all age groups to get wider view and experiences of relevant eGov services. For quality assurance and to sharpen the analysis, we had multiple follow-ups to resolve potential conflicts or dual interpretation of statements made by interviewees.

Table 1: Interviewees by sectors and age

\begin{tabular}{|c|c|c|c|c|c|}
\hline \multirow{2}{*}{ Sectors } & \multicolumn{4}{|c|}{ Age Group } & \multirow{2}{*}{ Sub-total } \\
\cline { 2 - 6 } & $15-24$ & $25-44$ & $46-64$ & $65+$ & \\
\hline \hline Academics & 0 & 3 & 4 & 1 & 8 \\
\hline Corporates & 0 & 1 & 2 & 0 & 3 \\
\hline Government & 1 & 1 & 2 & 1 & 5 \\
\hline Citizens & 14 & 12 & 16 & 8 & 50 \\
\hline Total & 15 & 17 & 24 & 10 & $\mathbf{6 6}$ \\
\hline
\end{tabular}

\section{Danish e-Government}

For two decades, Denmark has continuously been placed in the global vanguard vis-a-vis the various eGov services and infrastructures. The national digital infrastructure has for a long time consisted of key enablers; $C P R$ as a personal registration number, $N e m I D$ as a secure personal authentication and signature solution used when accessing online public/ private, services, Digital Post as a secure two-way communication, email and archive system used by citizens/businesses/public organizations, NemLogin as public authentication system, and NemKonto as a single bank account registry that connects citizens and businesses with the government to receive social benefits or other types of payments.

In addition, various public portals were developed around 2010, providing highly reliable information (no login required), links to transactional services (with or without login depending on data processed and nature of service), and access to personal data (login required). These portals are now widely recognized and utilized by citizens and businesses. For example, there are portals for healthcare services (Sundhed.dk), tax services (Skat.dk), business (Virk.dk), and citizen services (Borger.dk). Approx. 20 years have passed since these portals were first launched, and they have become integrated into a part of citizens' and businesses' daily routine with some $90 \%$ of all high-frequency and high-volume service being requested and delivered online since 2015 [3]. 


\section{1. eGov strategic tools}

The progress of eGov in Denmark was supported by several modernization strategies published since 1983 [27], and multiple digital government strategies implemented and assessed in strategic cycles of approx. every four years since 2001. These modernization and digitization strategies were supported broadly across the political spectrum in Denmark. Each strategy had clear priorities and implemented cross-sectional cooperation models [7], [8]. The eGov strategies were underpinned by a joint, cross governmental action plan, with strategic success and operational performance criteria incorporated with concrete targets and milestones [9], [27]. To ensure progress and compliance with the jointly agreed strategies and action plans, the Danish government has over time strengthened its approach to governance, collaboration, and capacities within the public sector. The establishment of the Danish Agency of Digitization (DIGST) through the merger of various mandates and responsibilities in 2011was a big leap. As a specialized agency responsible for digitization, DIGST formulates or assists in formulation of eGov policies as well as key IT projects and programs. In turn, cross governmental consultation, joint steering committees, and working groups are established to both implement and facilitate monitoring, measurement and conflict resolutions in a coordinated and collaborative manner within and across the Danish public sector (i.e., at central, regional and local level) [9], [11], [28]. Progress was visualized, and became widely accessible as open data, and the milestones were widely announced to reach target groups, using multiple media channels.

\subsection{E-government strategy}

The Danish government has initiated digital strategies since the 1990s. The first vision for the information society was announced in 1994 as InfoSociety 2000 [19]. Since then, the following five strategies were implemented (see also in Table 2).

The first eGov policy (Towards eGov: Vision and Strategy for the Public Sector in Denmark 2001-2004) [15] set digital communication [29] as a main objective. It includes three priorities: the implementation of digital signatures, compulsory receipt of e-mails from businesses and citizens to governmental institutions, and the establishment of inter-organizational digital communication. (Shift from paper to digital communication).

The second eGov policy (Realizing the Potential 2004-2006) [17] set efficient payments and digitization within public organizations as the main objective. There were three priorities: introduction of NemKonto as a single bank account system and eInvoice as electronic invoice system, deployment of several portals, and secure communication between public administrative organizations.

The third eGov policy (Towards Better Digital Service, Increased Efficiency and Stronger Collaboration 2007-2010) [21], [30] set the construction of a common infrastructure as the main objective. Again, there were three priorities: introduction of more secure personal authentication (NemID, NemLogin), an electronic tax payment system, and a mandatory use of common infrastructure by public institutions.

The fourth eGov policy (The Digital Path to Future Welfare, 2011-2015) [18] set digital communication and service delivery as a key objective. Under the heading "Those who can must use digital solutions" [31], the four priority areas included: mandatory use of Digital Post, mandatory online selfservice by citizens and businesses, enhancement of digital welfare, and basic data programs.

The fifth eGov policy (A Stronger and More Secure Digital Denmark, 2016-2020) [16] set improvement of usability, contribution to economic growth, and improvement of security as objectives. The priority areas are data reuse, establishment of a common public electronic architecture, collaboration with industry and private institutions, and improved data protection and cybersecurity. Following a pandemic interlude, a new strategy is planned from 2022.

Table 2: Danish e-Government Strategies

\begin{tabular}{|c|c|c|l|}
\hline & Year & $\begin{array}{c}\text { Main } \\
\text { Objective }\end{array}$ & \multicolumn{1}{c|}{ Priorities } \\
\hline 0 & $\begin{array}{c}1994- \\
2000\end{array}$ & $\begin{array}{c}\text { Digital as } \\
\text { central strategy }\end{array}$ & $\begin{array}{l}\text { - Various systems, standards } \\
\text { - Infrastructure and skills }\end{array}$ \\
\hline 1 & $\begin{array}{c}2001- \\
2004\end{array}$ & $\begin{array}{c}\text { Digital } \\
\text { communication }\end{array}$ & $\begin{array}{l}\text { - Digital signature } \\
\text { - Compulsory to receive } \\
\text { digital mails from citizens } \\
\text { - Inter-org. comm. }\end{array}$ \\
\hline 2 & $\begin{array}{c}2004- \\
2006\end{array}$ & $\begin{array}{c}\text { Digitization } \\
\text { within public } \\
\text { organizations }\end{array}$ & $\begin{array}{l}\text { - Digital transactions } \\
\text { - Portals } \\
\text { - Secure communication }\end{array}$ \\
\hline 3 & $\begin{array}{c}2007- \\
2010\end{array}$ & $\begin{array}{c}\text { Common } \\
\text { infrastructure }\end{array}$ & $\begin{array}{l}\text { - Secure ID, eTax } \\
\text { - Mandatory digital use of } \\
\text { public institutions }\end{array}$ \\
\hline 4 & $2011-$ & $\begin{array}{c}\text { Digital } \\
2015\end{array}$ & $\begin{array}{l}\text { - Mandatory Digital Post } \\
\text { - Mandatory self-service } \\
\text { - Digital welfare }\end{array}$ \\
\hline 5 & $\begin{array}{c}2016- \\
2020\end{array}$ & $\begin{array}{c}\text { Stronger and } \\
\text { more secure } \\
\text { digital } \\
\text { communication }\end{array}$ & $\begin{array}{l}\text { - Basic data } \\
\text { - Data reuse } \\
\text { - Common architecture } \\
\text { - Inter-collaboration } \\
\text { - Data protection \&Security }\end{array}$ \\
\hline
\end{tabular}


Throughout the process, mandatory digitization took gradual steps, starting within public organizations, moving to businesses, and lastly citizens in interaction with public authorities, spanning several years. The process was based on cooperation between the different levels of the public sector and between the public and private sectors, particularly to increase productivity, eliminate or minimize administrative burdens, and create public-private partnerships for key enabling infrastructure such as Digital Post, NemID and core standards for e.g. interoperability [7], [9].

\section{The exercise of mandate}

By reviewing the historical trajectory of Danish eGov development, it is evident that a cyclical approach is applied. Essentially each strategy is initiated by an assessment of the previous strategy cycle and aims to continuously improve performance. This has included the strengthening of mandates, approach to performance measurements etc. This section introduces three major events of eGov application which may be regarded as mandatory initiatives.

\subsection{Mandatory personal number}

$\mathrm{CPR}$, is a mandatory unique personal identifier given to each inhabitant in Denmark. Tracing its history, the enforcement of the Danish Act on Civil Registration in 1924 introduced the numbering system to Danish residents, managed by local governments. The population register was later centralized with the revision of the Act in 1968. Thus, CPR became the unique identifier, i.e. the official identity number, applied across all areas of public administration, including tax payment, medical care and education [32].

Whether the residents were willing to acquire their own number or not, CPR became mandatory and is now allocated at birth or when granted residency. While there was broad political support for the CPR when introduced in 1968, public discourse was not without controversy, and some people expressed anxiety about the "Orwellian" and coercive nature of being managed by numbers. However, today, the CPR is a key enabler, and is considered a natural part of daily life by most Danes, who use it to open bank accounts, subscribe to the internet or gym, register for medical services, or even to confirm their identity when entering polling stations on election day. In short, the CPR roots deeply in the social fabric, the administrative processes of the public and private sectors, and the country's digital infrastructure.

\subsection{Mandatory digital communication}

The Danish government has made various efforts to promote digitization widely and steadily across society. The e-Days' milestones were applied with the digitization of central and local governments (e-Day 1 in 2003, e-Day 2 in 2005 under the $1^{\text {st }}$ and $2^{\text {nd }}$ strategy), later digitization penetrated into private businesses related to the public (e-Day 3 in 2011, under the $4^{\text {th }}$ strategy). Finally in 2014, digitization reached citizens (e-Day 4 in 2014 under the $4^{\text {th }}$ strategy). While the earlier e-Days had focused on mandated deadlines for the public sector to adapt and apply specific technical solutions such as single sign-on across government solutions (i.e. NemID and Nem Login), e-Day 4 was an epoch-making event defining the final digital transition date for all public authorities and citizens to receive and send digital communications as mandatory digital transformation. Essentially Denmark changed its strategy from a voluntary opt-in to an active opt-out of digital communication, including use of NemID, Digital Post and 70 high-frequency and high-volume services [8], [18].

As shown in its trajectory, the shift one-Day 4 happened not on a single day, but rather spanned 12 years. Civil servants, consisting of one-third of the Danish working population, began using personal authentication systems and public digital systems already around 2003, and many businesses had also experienced digital communication with public authorities by 2011. In practice, NemLogin was also used by all Danish banks, as the system was established in cooperation with the financial sector. This suggests that when NemLogin, and Digital Post were made mandatory in 2014 , the majority of citizens had already experienced them to a certain degree. This step-by-step progress of nationwide digital shift has helped citizens become accustomed to digital services. It is important to mention that although compulsory, citizens with special needs can apply for an exemption from digital communication with public institutions.

\subsection{Mandatory self-service}

The digitization of various public services, and their development as self-service, was implemented step-by-step, from the areas with high-volume and/or high frequency of use [16], [18], [23]. Public services that were digitized as citizens' self-service in the early stage included: change of resident address, business establishment, admission applications for higher education[3], the Danish state educational grant application for students, admission to elementary school [33], family benefits for single parents [13], hunting licenses and others. 
Regarding the change of resident address, the selfservice implementation was relatively easy and simple because the central resident registration system had already functioned for decades. Similarly, digital selfservice for business establishment has progressed relatively smoothly since the corporate number system, the CVR number, was implemented in 1999.

The digital shift was also aggressively promoted in the higher education area, such as with digital applications and the Danish state educational grant application process for students. A law on digital selfservice for the application for admission to higher education was enacted in 2011 and enforced from 2012. The targeted users of such public services are so-called digital natives. When the application process was digitized, the targeted service users were forced to use digital means. The prioritization of this domain for digital implementation was a strategic success, as the target users are mostly highly capable of using the provided digital tools and services. The conventional paper-based application for admission was, on the contrary, very complicated since the application forms had to be filled out by following a thick manual. If any mistake were made on the form, it was necessary to go to the admission office and obtain a new paper application form. Critical incidents occasionally happened. The Danish admission period is around summer holiday season, when some students would go on vacation and miss the deadline. Also, since the applications were sent by the conventional postal service, which has limited resources during the summer period, students were always terrified of delays and loss. As easily imagined, self-service digital application became one of the best digital transition cases in public services.

The Danish government did not digitize all administrative procedures at once. They strategically selected the target services and processed step-by-step, considering human and social capability rather than technical availability. The implementation of digital self-service has created and accumulated successful cases including $100 \%$ digital communication between government and businesses and acquired a high reputations which has led to positive evaluations on eGov in general.

\section{Analysis}

Based on the data obtained from the governmental reports, literature reviews and interviews, we analyzed the reasons behind Danish eGov service usage, especially in relation to the eGov mandatory service implementations and their acceptance. Our data analysis extracted a total of 221 aspects. Based on the consequent data synthesis [25],[26], four categories and nine features were identified as keys for eGov mandate acceptance. The result is shown in Table 3.

Table 3: Keys for eGov mandate acceptance

\begin{tabular}{|c|l|}
\hline \multicolumn{2}{|l|}{ Pride as citizen } \\
\hline 1 & Being taken for granted \\
\hline 2 & Understanding of social and political system \\
\hline 3 & Accumulating sense of duty as citizens \\
\hline Trust and Privacy \\
\hline 4 & Trust in public authorities \\
\hline 5 & Less worries about privacy \\
\hline Access and usability \\
\hline 6 & High usability such as learnability \\
\hline 7 & High accessibility for diverse users \\
\hline Informal supports \\
\hline 8 & Timely support by family \\
\hline 9 & Reciprocal community support \\
\hline
\end{tabular}

\subsection{Pride as citizens}

In Denmark, when any online public services were made mandatory, the government spent enough time and effort to disseminate them widely. Approx. 30 and 18 years have passed respectively since the beginning of the modernization program of the public sector in 80s [27] and the introduction of digital communication in the 2000s [29]. Also, although it was not a conscious strategy, CPR had already been used for approx. 50 years, when Danish eGov started to utilize CPR widely in its public services. This means the service and the related technologies were already embedded and taken for granted by citizens as part of their daily life.

DIGST, with key stakeholders, identified potential service areas. As a rule, the simpler the process, the higher the frequency and volume of a service area, the earlier it become mandatory to use online, e.g. change of address, applications for various grants and licenses. Rich relevant information and training campaigns at schools, libraries and parks were also strategically launched nation-wide and coordinated by all levels of governmental functions through specific working groups and private organizations between 2011-2015 [34]. To address the digital divide challenge, DIGST developed a usability guide setting a minimum standard for online userfriendliness for government websites and online services. DIGST also collaborated with 
representatives for persons with disabilities, special needs, and seniors, conducted tailored and targeted information marketing, and provided free digital literacy training. Furthermore, it was a big help that banks used the same NemID procedures as the public sector. Even people who did not have frequent communication with the public sector knew how to use NemID as authentication to log-in to public services.

Learning from the UK, DIGST allocated $10 \%$ of the eGov budget specifically to disseminate knowledge to the public widely and effectively. As a result, a wide variety instruments for information dissemination were used by diverse stakeholders. For example, several events were held with music concerts in front of the Copenhagen city hall. At one venue, while famous musicians sang, a Digital Post registration counter was set up, where citizens had an opportunity to register and learn Digital Post on the spot. In our interview, such governmental efforts were occasionally mentioned.

I remembered politicians held press conferences repeatedly, expressing how essential digitalization was to maintain the welfare state of Denmark with high quality, and that it is necessary for the citizens to work together to the digitalization. I thought Wow! (Citizen 12).

With the coordinated and targeted campaigns, and consequent improved familiarity with digital services, even the most skeptical citizens were exposed to them to some extent in their daily lives [13]. Many interviewees mentioned they knew they had to use eGov solutions, and so they did. At the same time, allowing citizens to contact local authorities to ask for a limited two year or permanent exemption softened the obligatory elements of the mandatory approach. While actively communicated as "mandatory" digital communication and online self-service, rather than coercive dirigisme, this aggressive message was mainly pedagogical in nature, as citizens and businesses now had to actively opt-out of the digital challenge and apply for an exemption. Similarly, call and physical service centers, particularly for social security, healthcare and local government services remained in place to support those in unique situations, or who did not have internet access or the required digital skills.

Figure 1 shows the usage of Digital Posts 2.5 years (in 2017) and 4.5 years (in 2019) after the mandatory digital transition in 2014. The citizens between 18-84 years old have the similar "did not open/read" rate of Digital Post between 1.8\%-5.7\%. Of the $85+$ year old $7.1 \%$ did not open received digital messages 2017, compared to $4.6 \%$ in 2019 for at least
6 months. Interestingly, the same statistics show "not open" rate for $15-17$ years old was $21 \%$ in 2017 and $17 \%$ in 2019 , i.e. almost three times as bad as the senior generation [35]. In fact, while the strategic target was $20 \%$, only $10 \%$ of all Danes had actively requested exemptions from mandatory digital communication by 2017 [35].

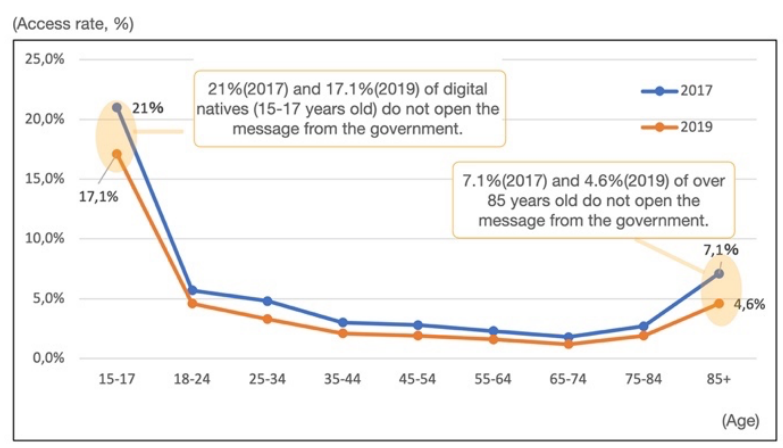

Figure 1: Open rate of Digital Post [35]

The above anecdotal evidence suggests that seniors were in fact the first to adjust to the new digital by default approach. The temporary exemptions were effective to minimize the sense of personal uncertainty, stress and potential coercive dirigisme associated with mandatory changes. These large-scale national exercises in change management and behavioral change have likely contributed to making citizens actively try and comply with the mandatory obligations communicated, even if not accustomed to digital tools. A sense of civic duty to change behavior may have been nourished, while the "mandatory" communication messages may have had a psychological and pedagogical impact on those endusers already online but who had simply not changed their habits.

\subsection{Trust and privacy}

Another factor of Danish eGov success has been linked to a high level of trust between public sectors and citizens. Denmark has been regarded as a country where citizens generally trust authorities the most in the administrative usage and management of personal information [36], and where citizens are generally not concerned about privacy issues through information sharing with authorities [13]. This is also reflected in the Corruption Perceptions Index [37], where Denmark and its public sector is consistently ranked as one of the least corrupt globally. This genuine trust in authorities could be one of the reasons why mandatory approaches can be accepted by citizens in eGov services. One of the citizens said. 
It is not comfortable to be forced to use any public services. But, at the same time, I enjoy sharing my data with authorities, for example, my vaccination record. They take good care of us. (Citizen 7)

The tools used by Danish eGov to gain trust are very simple ethical approaches [38], although difficult to practice, which are ensuring deeper transparency and promoting open data [36]. The government establishes laws, rules and processes for handling personal data to ensure high transparency, and discloses the eGov policy as open data, including prompt information sharing of any data leakage. For example, Citizen 27 mentioned her experience.

I checked who accessed my data online. I can see them handled properly. Occasionally, the system asks if I want to share my data or not, which guarantees high transparency of handling citizens' data (Citizen 27).

The government efforts to secure data and privacy have clearly achieved and accumulated national trust over years. However, this does not mean there have not been data leaks or security alerts. High trust record in public sectors does not necessarily guarantee that any actions from government are accepted without questions or objections from stakeholders or citizens.

For example, in 2020, Denmark struggled with the low take-up numbers of the COVID-19 tracking app, Smitte|Stop [39]. Like other countries, Denmark introduced the app in 2020 to stop the COVID-19 spread. However, the number of users on the app stagnated for months. Later analysis found that it was not the ability to use the app, but rather a lack of trust in the app which had resulted in the limited take-up. While most citizens found it easy to use the app, they did not deem it useful, or they had privacy concerns. The latter was in large part due to a series of system and data errors in the early days, and a prevailing misunderstanding of its tracking function, and its use and handling of data [40]. Similar critique of a number of the tax agency's IT-systems, or its handling of past identity thefts are the subject of ongoing public debate and critique from citizens and IT professionals [41], [42].

In short, even in a country like Denmark, which enjoys high levels of trust between authorities and citizens during ordinary times, trust is fragile and may easily be lost. Citizens may easily become less tolerant and have lower acceptance levels towards something unknown and have concerns about privacy and misuse of data. The limited take-up of the COVID-19 tracking app and other examples show the importance of continuous efforts in building and maintaining trust in this type of relationship.

\subsection{Access and usability}

Another reason for the acceptance of mandates was that eGov services had a minimum level of accessibility and usability. During the $4^{\text {th }}$ strategy national guidelines for a minimum level of userfriendliness were adopted, including responsive webdesign and a device-independent design approach [18]. Users' acceptance of eGov services were early identified as largely influenced by the end-users' perception of the quality and user-friendliness of eGov services, in particular effectiveness, efficiency, utility and learnability, which are all associated with usability goals [43]. With high usability, eGov services would enjoy wider acceptance by ordinary citizens, as well as different socio-economic segments and people with diverse physical and mental challenges.

Without a critical mass of use, investments in eGov solutions would not achieve their expected outcomes. In part inspired by the UK's success with digital by default and service design standards, the Danish government paid attention to its usability and diverse needs to fulfil every possible challengs [18]. Existing services were assessed for usability and web accessibility twelve months prior to becoming mandatory for online use. This allowed for critical improvements of form and function, or even the complete redesign of services [44]. The changes were agreed as part of a cross-governmental steering committee managing the strategy's action plan. Assessments were made in relation to the national standard for online usability and web accessibility, developed specifically for the purpose to ensure a minimum level of user-friendliness and look-and-feel across all government service offers online [45], [46].

As part of the usability guide, installation of specific software, browsers or even apps to use a specific solution was barred in the public sector. This helped to lower the barrier for usage for all; not least weak IT users. In fact, 16 respondents aged above 65 years mentioned that they often get help to update software, install apps, or replace hardware. However, with some help, they can use the service freely once it becomes a part of their daily routine.

As a result, high usability and accessibility, intuition and basic digital skills enabled use of eGov services, independent of age, gender, skills or socioeconomic background. An interviewee in his early 30's highlighted his positive experience when using the digital application.

It doesn't matter whether it was mandatory or not. It was clearly easier to use digital than the conventional paper-based applications. We will never miss the deadline via net, while the legendary Danish 
postal service could easily lose important documents. (Citizen 23)

\subsection{Informal supports}

Even as citizens with a high level of trust and a strong will to use online service, some user groups, such as seniors at $85+$ and persons with disabilities and special needs, have difficulties in using eGov services. However, these groups still accepted the mandatory use of eGov services in Denmark. According to DIGST [35], only $10 \%$ of citizens are waived from eGov services in 2017, which means that $90 \%$ of citizens over 15 years old use the eGov services on a regular basis. As mentioned previously, the high level of adoption amongst citizens with challenges was in part facilitated by a public commitment to ensure online usability and web accessibility of all public websites and e-services. Furthermore, the ability to opt-out, and allowing the vulnerable to access alternative channels such as call and physical service centers, helped minimize resistance to change [18].

The $90 \%$ usage does not necessarily mean that all Danish seniors using eGov solutions have high digital literacy. Some of the 65+ interviewees emphasized that they sometimes get assistance from family or friends for some public related administrative tasks such as paying tax and applying for benefits, for instance when at family functions. Children and grandchildren often assist seniors. Although this is not an explicit part of the eGov strategy or communication activities, family support is nonetheless another reason for the acceptance of mandated use of online services.

Furthermore, Denmark has developed reciprocal communities within society. Some associations such as Denmark's largest senior association and associated trade union (Aeldresagen and Faglige Seniorer), and diverse patient groups, function as support for their members. When the eGov policies were developed, public institutions collaborated with the various stakeholder organizations [16], [18]. For example, senior groups collaborated with local municipalities to hold IT Cafes in meeting rooms of public libraries. At monthly IT Cafes, seniors with digital skills act as instructors, explaining how to use various digital public service offers, online security etc. Depending on participants' needs, the instructions vary from how to use public portals and Digital Post, to how to check pensions online or pay bills using online banking.

\section{Discussion}

Could mandatory digital services be accepted by citizens? Our data shows that it seems the case in Denmark. Underpinning the success of the mandatory online services, are four preexisting enablers, specifically: pride as citizens, a high level of trust and privacy, usability and accessibility of eGov services, and informal support by family and community networks. The Danish case indicates that mandatory use and active opt-out policy approaches can be an incredibly efficient and effective way to promote eGov services, but this is in part depending on the local context. If not, such mandated and mandatory approaches could be seen as coercive or authoritarian.

A second key question will be whether the Danish approach is transferable to other socio-political and cultural contexts. In the European context, the Nordic countries of Finland, Iceland, Norway, Sweden, and Estonia have adopted similar active opt-out approaches. Similarly, the Netherlands have adopted a mandatory online service use, albeit mainly for solutions targeting digital natives such as students, or for legally required obligations such as tax returns or various licenses. In the European context, the mandatory approach to online service use is seen for most business services; similarly in other OECD countries, and G20 countries as diverse as Brazil, Saudi Arabia and South Africa. For citizen services, countries like Australia, China, South Korea and Japan, have applied a mandatory approach to selected online services, such as pensions, unemployment benefits, parental leave etc.

Countries like Estonia and South Korea, which have similarly high levels of online service use to Denmark [4], have few of the same contextual and socio-economic conditions as Denmark. Estonia achieved a high level eGov services, strengthened by a sense of national pride in the E-Estonia story and brand, despite less user-friendly online services [6], [47], [48]. Estonia has its strategic focus, coordinated approach, digitally skilled population, and a high degree of trust in the way government handles technology and data. South Korea have focused on usability, although the level of trust in the public sectors' use of technology has not always been present [11].

Conversely, Japan met strong resistance to the mandate introductory of the Basic Resident Registration Network System (Juki Net) and citizens' digital ID (Juki Cards) and current MyNumber system and related services [1], [30], [52], [53]. Similar stories have played out in the Faroe Islands. The Faroe Islands, which has a relatively similar socio-cultural and political context to Denmark (formally part of the Danish Commonwealth), met strong resistance to the introduction of a unique personal number (or Pnumber) for the new tax payment system in 1984 [6]. As a consequence, the scope of ID use was severely restricted and another, later digital ID, MyKey was 
introduced in 2015 in parallel with the P-Number [7],[53]. Similarly, Anglo-Saxon countries like Australia and the UK, pursue a voluntary opt-in approach to digital identification (eID) despite some citizen and most business services often being the main service channel (as physical and call centers are only used for queries). Globally many citizens remain skeptical of the whole-of-government approaches, and dislike mandatory government initiatives and data sharing [9]. As a result, some governments had to abandon ICT solutions, as the expected benefits have not materialized.

In many cases, democratic governments seen as enforcing policy or mandating behavioral change, will often face strong resistance, and lose public support. As shown, there are already several national eGov related projects worldwide that were demolished in the end due to lack of citizen support or stagnating usage of services, despite enormous investment. These cases indicate that mandatory digital transition without sufficient preparation and consideration of socioeconomic, political, and cultural contexts, could not produce the expected effects, and may in some instances even be counterproductive.

Our analysis indicates that the key enabler is not the mandated use of online solutions, but rather combined factors - as evident from e.g. the Faroe case. The four categories and nine features highlighted by interviews and analysis may seem simple. However, the authors consider that the mentioned factors created strong potential to make people accept the mandatory realization of Danish eGov services. Previous research [56] shows that active strategic marketing can guide citizens to use eGov services, however, as our analysis shows, marketing is just one aspect of a set of necessary contextual factors. Reflecting on the behavior of the younger generations in Denmark, it was necessary to increase their social understanding, and their sense of duty (e.g. appeal or social pressure), alongside building trust and ensuring user-friendly service design. [13]

\section{Remarks and conclusion}

Using the Danish eGov case, this paper analyzes mandatory eGov service use as a potential strategic tool to promote the smooth introduction of eGov services. More importantly, the analysis unearths several factors for the success of this approach in the Danish context. The article tries to illustrate success criteria behind the mandate by highlighting four aspects observed in Denmark during the digital shift.

It is important to note that the word, "mandatory", as we used throughout this paper, was only to highlight a certain aspect of the Danish eGov actions. In effect, it intends to imply "digital-by-default with an active opt-out strategy", rather than coercive dirigisme. While governments might play a strong directive role, Denmark attempts to present its digital path as valuable and beneficial to all citizens with a degree of social commons, which has gradually become a shared societal and joint-governmental message. Small welfare states like Denmark, while relatively wealthy, do have finite resources. Digitization aims to increase public sector productivity and to strengthen national competitiveness, maintaining quality of life and high service levels. Citizens reacted to such messages.

The mandated and mandatory approach have been successful in Denmark due to key conditions and factors. As such the contribution of this analysis does not lie in the understanding of successful mandatory service implementation but in the identification of the four categories and nine features which enabled the Danish government to increase citizen use of online services. It is these enablers and features which will be relevant for other government authorities to identify and apply in their national contexts.

In conclusion, it should be noted that this analysis certainly has several limitations. The analysis focuses on a single country. Future analysis would therefore be relevant to validate and compliment the findings of this analysis. Of particular interest is to identify the applicability of the four supportive prerequisites in similar socio-economic, political, and cultural contexts, especially in relevant countries where the roles of public and private players are different, where factors such as trust are missing, or where degrees of communalism or dirigisme vary. It would therefore be of value to investigate further and analyze whether the enablers derived from this investigation can guarantee its validity in a wider context.

\section{Reference}

[1] N. Igari, "How to successfully promote ICT usage: A comparative analysis of Denmark and Japan," Telemat. Informatics, vol. 31, no. 1, pp. 115-125, 2014, doi: 10.1016/j.tele.2012.10.001.

[2] J. Schou and M. Hjelholt, Digitalization and Public Sector Transformations. Palgrave Macmillan, 2018.

[3] A. Scupola, "Digital Transformation of PublicAdministration Services in Denmark:A Process Tracing Case Study," Nord. Balt. J. Inf. Commun. Technol., vol. 2018, no. 1, pp. 261-284, 2019.

[4] UN, Department of Economic and Social Affairs Population Div., E-Government Survey 2020. UN, 2020.

[5] M. Meyerhoff Nielsen, "E-governance and stage models: Analysis of identified models and selected Eurasian experiences in digitising citizen service delivery," Electron. Gov., vol. 12, no. 2, pp. 107-141, 2016, doi: 10.1504/EG.2016.076132.

[6] K. McBride, "Sailing towards digitalization when it 
doesn't make cents? Analysing the Faroe Islands' new digital governance trajectory," Isl. Stud. J., vol. 14, no. 2, pp. 193-214, 2019, doi: 10.24043/isj.93.

[7] M. Meyerhoff Nielsen and M. Yasouka, "An analysis of the Danish approach to eGovernment benefit realisation," Internet Technol. Soc. 2014 Conf. Proc., pp. 47-58, 2014.

[8] M. Meyerhoff Nielsen, "The Role of Governance; Cooperation; and eService Use in Current eGovernment Stage Models," in the 49th Hawaii International Conference on System Sciences (HICSS), pp. 2850-2860. 2016.

[9] M. Meyerhoff Nielsen, "Governance lessons from Denmark's digital transformation," in Proceedings of the 20th Annual International Conference on Digital Government Research, 2019, pp. 456-461, 2019.

[10] I. Mergel et al., "Policy and Process Tracing of International Digital Transformation Practices," 2018.

[11] M. Meyerhoff Nielsen and Z. Jordanoski, "Digital transformation, governance and coordination models: A comparative study of Australia, Denmark and the Republic of Korea," in 21st Annual International Conference on Digital Government Research, 2020.

[12] F. D. Davis, "Usefulness, Perceived Ease of Use, and User Acceptance of Information Technology," MIS Quarterly, vol. 13, no. 3, pp. 319-3403, 1989.

[13] C. Ø. Madsen and P. Kræmmergaard, "The efficiency of freedom: Single parents' domestication of mandatory egovernment channels," Gov. Inf. Q., vol. 32, no. 4, pp. 380388, 2015, doi: 10.1016/j.giq.2015.09.008.

[14] B. Niehaves and R. Plattfaut, "Internet adoption by the elderly: Employing IS technology acceptance theories for understanding the age-related digital divide," Eur. J. Inf. Syst., vol. 23, no. 6, pp. 708-726, 2014.

[15] Den Digitale Taskforce, "På vej mod den digitale forvaltning-vision og strategi for den offentlige sektor" 2002.

[16] The Danish Government, Local Government Denmark, and Danish Regions, "The Digital Strategy - A stronger and more secure digital Denmark," 2016.

[17] Den Digitle Taskforce, "Den offentlige sektors strategi for digital forvaltning 2004-06 - realisering af potentialet," 2004.

[18] The Danish Goverment, Danish Regions, and Local Government Denmark, "The digital path to future welfare eGovernment strategy 2011-2015,” 2011.

[19] Ministry of Research and Information Technology, "From Vision to Action: Info Society 2000," 1995.

[20] OECD E-Government Studies, OECD e-Government Studies: Denmark. 2006.

[21] OECD E-government studies, "Denmark: Efficient EGovernment for Smarter Public Service Delivery," OECD, 2010.

[22] European Commission, "E-Government In Denmark," 2015.

[23] European Commission, "eGovernment in Denmark," 2016.

[24] European Commission, "Digital Public Administration factsheet 2020, EU," 2020.

[25] R. Scupin, "The KJ method: A technique for analyzing data derived from Japanese ethnology," Hum. Organ., 1997.

[26] D. Walsh and S. Downe, Meta-synthesis method for qualitative research: A literature review, vol. 50, no. 2. 2005.

[27] N. Ejersbo and C. Greve, Moderniseringen af den offentlige sektor, 3rd ed. Akademisk Forlag, 2014.

[28] M. Meyerhoff Nielsen, "Egovernance frameworks for successful citizen use of online services: A Danish-Japanese comparative analysis," eJournal eDemocracy Open Gov., vol. 9, no. 2, pp. 68-109, 2017.

[29] DIGST, "Digital kommunikation." https://digst.dk/.(accessed May 24, 2021).

[30] The Danish Government, Local Government Denmark, and Danish Regions, "Towards Better Digital Efficiency and Stronger Collabofration-Danish EGovernment Strategy 2007-2010,” 2007.

[31] DIGST, "Lovgivning om obligatorisk digital selvbetjening." https://digst.dk/ (accessed May 24, 2021).

[32] T. Jerlach, "CPR kontoret -Udviklingen på CPRområdet i de seneste 20-25 år frem til 2009.," 2009. https://cpr.dk/media/ (accessed May 24, 2021).

[33] J. Schou and M. Hjelholt, "Digital citizenship and neoliberalization: governing digital citizens in Denmark," Citizensh. Stud., vol. 22, no. 5, pp. 507-522, 2018.

[34] Digitaliseringsstyrelsen, "Kampagne for digital post," 2014.

[35] L. P. Kampamann, "Digitizing the public sector - The Danish model," 2017.

[36] M. Marozzi, "Measuring Trust in European Public Institutions," Soc. Indic. Res., vol. 123, no. 3, pp. 879-895, 2015, doi: 10.1007/s11205-014-0765-9.

[37] Transparency International, "Corruption Perceptions Index." https://www.transparency.org/ (accessed Jun. 04, 2021).

[38] J. Koskinen, M. M. Rantanen, and S. Hyrynsalmi, "Ethical governance of e-government ecosystem," no. June, pp. 201-215, 2021, doi: 10.18690/978-961-286-362-3.14.

[39] DIGST, “smitte|stop." https://smittestop.dk/ (accessed Jun. 06, 2021).

[40] M. T. Larsen, Smitte Stop, Roskilde University. 2020.

[41] DR, "'Vildledende" og "mangelfuld"," 2020. https://www.dr.dk/ (accessed Jun. 15, 2021).

[42] DR, "NemKonto misbrugt til svindel i årevis," 2020. https://www.dr.dk/ (accessed Jun. 15, 2021).

[43] J. Nielsen, Usability Engineering. Morgan Kaufmann, 1993.

[44] L. Nielsen and K. S. Hansen, "Personas is applicableA study on the use of personas in Denmark," Conf. Hum. Factors Comput. Syst. - Proc., no. May 2014, pp. 16651674, 2014. , doi: 10.1145/2556288.2557080.

[45] DIGST, "God selvbetjening: Udviklingsvejledning forselvbetjeningsløsninger."https://www.digitaliser.dk/ (accessed Jun, 11, 2021).

[46] DIGST, “Det Fælles Designsystem.”https://digst.dk/ (accessed Jun. 11, 2021).

[47] M. Meyerhoff Nielsen, "E-Governance and online service delivery in Estonia," ACM Int. Conf. Proceeding Ser., vol. Part F1282, pp. 300-309, 2017.

[48] C. Benevolo, R. P. Dameri, and B. D. Auria, "Empowering Organizations: Enabling Platforms and Artefacts," vol. 11, no. May, p. 315, 2016.

[49] Talgildu Føroyar, "The National Digitalisation Programme of the Faroe island," 2015. 